\title{
Pedagogical Features Of Moodle Platform
}

\author{
Norbek Isakulovich Taylakov, \\ Doctor of Pedagogical Sciences, professor, Uzbek Research \\ Institute of Pedagogical Sciences named after Qori-Niyazi, \\ Uzbekistan.
}

\author{
Fotima Urazalievna Anarbaeva \\ Samarkand State Institute of Foreign Languages, \\ Uzbekistan.
}

\section{Gopen access}

The American Journal of Applied Sciences

JULY 2020

Page No.: 104-107

Volume-II Issue-VII

PUBLISHED: 31 JULY 2020

www.usajournalshub.com/inde

x.php/tajas

Copyright: Original content from this work may be used under the terms of the Creative Commons Attribution 4.0 licence.

\section{Abstract}

This article discusses ways to improve the pedagogical capabilities of the Moodle platform. Based on the Five Principles of the Moodle platform, the main components of the educational process, elements and possibilities of the structure of the distance course are considered.

Keywords: Moodle platform, distance course, teacher-student relationship, principles, instructional material, course structure, motivation, curriculum, educational resources, resource.

\section{Introduction}

At present, there has been a need for modern techniques, techniques, requirements for the creation of educational tools and models in higher education.

Through modern technologies, the demand for professional training of teachers also increases as a result of the increasing use of scientific and educational information to educators.

One of the major problems of modern higher education is the problem of training the staff of professors to work in the process of automation of Education. Taking this into account, when transferring the process of higher education to distance learning, it is important to choose the necessary platform for exchanging communication with students and providing education to students. And the Moodle platform was considered an important choice in our opinion. In this study, the features of Moodle platform, the principles of creating a remote course, and the basic elements of the course structure are considered. 


\section{Materials and methods}

The Moodle platform is a system that focuses on a distance learning model designed to enable students in groups to be educated at the same time. Its foundation is laid by such principles as Vigotsky, Djon Dyui, Jean Piaje, Ernst fon Glazerfeld. On the basis of these principles, Martin Dujiamas (Martin Dougiamas) (author and head of the project on the creation of the MOODLE education management system) formulated five principles laid down in the system under the name of "social constructivism", and on the basis of these principles developed the basis of the pedagogical capabilities of the Moodle platform.

Given these principles, it is possible to consider the main components of distance education, such as the subjects of education, the communication systems between them, and the area in which the learning process takes place. The distance learning model envisages the transmission of information in a special information and learning environment (virtual) as a key component. The specificity of the field radically affects all components of learning activities: learning motivation, learning situation, monitoring and evaluation of student knowledge.

All components of educational activities are primarily the appearance of teacherstudent relationships through the Moodle platform.

The second important feature is the transmission of educational resources to students, educational resources are transmitted to students as information, instructional materials, meta-data. Then the student assesses and evaluates the knowledge as a result of the information received. The work done by the student and the result evaluation received are stored in the student's database.

\section{Result and discussion}

The success of distance learning will largely depend on the proper organization of the learning material. If the distance course is oriented towards teaching, then the collection, sorting and placement of the materials necessary for the course is often organized on the basis of teacher and student interaction, and this is determined by the didactic properties of the course component. The creation of a distance course should be directed to the formation of the ability of students to independently acquire knowledge. In this case, the teacher must manage the learning process and control the acquired knowledge, skills and skills.

The means of preparation of the training material for the distance course are selected according to the curriculum.

For the Moodle distance learning system, the course structure should consist of the following elements:

1. The motivation block stimulates interest in effective cognitive activity, active mastering of key content. Motivation is a necessary part of a distance learning course and should be maintained throughout the entire learning process. Here, great attention is paid to the specific goal set for the students. If the level of issue put on does not correspond to the level of student preparation, the motivation is lost.

2. The instruction block consists of instructions and methodological instructions, normative documents, results of questionnaires, distance course schedule (course sections, assignments, tests, independent work), which are important for the participants 
of the training process. The instruction should be methodologically clear and understandable.

3. The information block includes printed textbooks and manuals, electronic textbooks and guidelines, assignments for laboratory and practical work, a list of basic and additional literature, additional materials on the course. On the Moodle platform, there are elements such as lecture, glossary, Flash Video, Scorm package, and resources such as Web page, hyperhavola to place data in this block.

4. The control block contains information that controls the learning process: current, intermediate and final control tests, questions for independent work, control tasks on topics.

At the same time, control work is an important factor in monitoring the student's mastery of distance learning resources, the formation of independent work skills.

5. The communicative and consulting block describes the interactive interaction of distance students with the teacher. The Moodle platform has tools such as lectures, forums, chats for interactive communication between teacher and student.

Consultation can be done individually or in groups (5-7 people at a time). They can be real (chat, ICQ, Skype, webinar) and asynchronously (email, forum, ads).

\section{Conclusion}

Based on the above, the formation of a distance course in an understandable and systematic way depends primarily on the pedagogical and professional skills of the teacher.

E-learning resources developed on the Moodle platform have many capabilities ${ }^{1}$ :

- allows you to effectively organize the learning process and independent work of students;

- through the introduction of new technologies and forms of teaching, it creates an opportunity for students to take an interest in learning;

- allows students to develop their professional competence;

- allows the quality of education and the level of education of students to increase;

- increases the social and professional preparation of students;

- ensures that students adapt to the knowledge they have acquired.

Moodle allows you to design, create and manage information and education resources. The system interface is designed to be easy and understandable for teachers who do not have sufficient knowledge in the field of programming and database management..

\section{References}

1. Marchuk N.Yu. Psixologo-pedagogicheskie osobennosti distantsionnogo obucheniya // Pedagogichesee obrazovanie $v$ Rossii I - 2013. - №4I

2. Kufley O.V, Dmitrienko I.A. Introduction of electronic training as a systemic factor of development of education I Ksla.kg. [Electronic resource] I URL: http://ksla.kg/ apalōda / fā'ila / vēsțanika / vestnik_2014_2 / 90-94.pdf I 
3. Kleynosova N.P., Kadyrova A.A., Telkov I.A., nirunichev R.V. // Proektirovanie i razrabotka distantsionnogo uchebnogo kursa v srede MOODLE 2.7: uchebnomotodicheskoe posobie /I - Ryazan: Ryazan I gos I radiotexn I nn-t, 2015 - I I 4. Anarbaeva na.U. Uttara №4 / 1I Tajik Pedagogical Institute in the city of Pendjikent I Pendjikent, 2018., strl 27-29 